\title{
The Effect of Green Coconut Water (Cocos Nucifera) before Aerobic Physical Activity on Pulse Recovery in Athletic Athletes
}

\author{
Jamaludin Yusuf ${ }^{1}$, Ainun Muthoharoh ${ }^{2}$, Muhammad Ghilang Maulud Setiawan ${ }^{3}$ \\ \{jamaludinyusuf@umpp.ac.id ${ }^{1}$ \} \\ Universitas Muhammadiyah Pekajangan Pekalongan, Pekalongan, Indonesia ${ }^{1,2,3}$
}

\begin{abstract}
Athletics is a sport with many numbers of matches, every athlete can take 2 numbers, this requires a nutrient that can help restore the pulse faster, especially in running numbers. The objective of this study is to determine the effect of green coconut water on the decrease in recovery pulse at the $5^{\text {th }}, 7^{\text {th }}$, and $9^{\text {th }}$ minute. The research method used in this study is pre-experimental design with one-group pretest-posttest design. The population of the study was athletes in Pekalongan Regency with 13 total sample. Materials/tools used are whistles, measuring cups, pencils, notebooks, green coconut water. The study was conducted in February 2020 at Widya Manggala Krida Stadium, Pekalongan Regency. This study uses two research variables: (1) independent variables: mineral water and green coconut water (2) dependent variables: recovery pulse $\left(5^{\text {th }}, 7^{\text {th }}, 9^{\text {th }}\right.$ minutes). The research data analysis technique was independent $t$-sample test. The test was carried out at a significant level of $p=0.05$. Statistical test results from the $t$-sample show that there is a difference in recovery pulse at the 5th minute $(\mathrm{p}=0.002)$, recovery pulse at the 7 th minute $(p=0,000)$, recovery pulse at the 9 th minute $(p=0.001)$. The conclusion in this study is that there is an effect of giving green coconut water drink before aerobic physical activity on the recovery pulse.
\end{abstract}

Keywords: mineral water, green coconut water, aerobic physical activity, recovery pulse

\section{Introduction}

Strenuous aerobic physical activity will cause a buildup of body fluids and lactic acid which is released through sweat. This fluid is highly sought after in order to maintain the body's balance process. [1] Argue that when the body lacks fluids, the body will experience dehydration. Very strenuous aerobic physical activity will affect the increase in pulse rate and the need for efforts to overcome this recovery [2].

Recovery is needed to restore the body's condition due to high intensity aerobic physical activity. The recovery period ranges from 5 to 9 minutes after activity, namely at the fifth, seventh and nine minutes. [3] Sweat during various activities depending on each individual. This activity causes the body to lose a lot of substances in the body in the form of minerals such as potassium, magnesium, zinc, sodium and iron. The function of sodium is as a regulator of $\mathrm{pH}$ in the blood, osmotic pressure and fluid balance do not cause pressure due to cell shrinkage [4]. What happens to fluid problems in the body will have an ongoing impact and affect the process of improving circulation in the body which is not normal so that changes in needs occur in other 
activities. In an effort to follow up on this problem, which researchers have the initiative to compare the effects of green coconut air before doing aerobic physical activity [5].

Young coconut water contains macro nutrients such as $4.11 \%$ carbohydrates, $0.12 \%$ fat, and $0.13 \%$ protein (7). Micronutrients in coconut water are vitamin B (B1, B2, B3, B5, B6, B7, B9) and vitamin C. The minerals in coconut water are N, P, K, Ca, Mg. $(7,20)$. Young coconut water contains the highest $\mathrm{K}$ element. Aqua water contains calcium 11-25 mg / 1, magnesium 6$22 \mathrm{mg} / \mathrm{l}$, potassium 1-8 mg/l, sodium 9-25 mg/l, bicarbonate 71-187 mg/l, chioride 1-25 mg/l, sulfate 2-33 mg/l, silica 62-87 mg/l, TDS 88-190 mg/l, pH 6.7-7.2 [6].

Young coconut water contains about $291 \mathrm{mg}$ of potassium per $100 \mathrm{ml}$ [7]. Young coconut water can normalize blood pressure. Potassium in coconut water balances the function of sodium in blood pressure imbalances [8]. Potassium lowers blood pressure is estimated by the mechanism of natriuresis in the kidney, endhotelium-dependent vasodilation, and the central effect through the renin angiotensin aldosterone (RAA) mechanism and an increase in the $\mathrm{Na}$ pump which decreases sympathetic nerve activity [7]. Potassium can lower systolic and diastolic blood pressure by inhibiting the release of renin so that it can help increase sodium and water excretion [9].

Many studies have examined the various uses of coconut water such as: 1) explained that young coconut water has a positive effect on improving pulse recovery [10], 2) concluded that $350 \mathrm{ml}$ coconut water is drunk 30 minutes before physical activity can accelerate the decrease in pulse [11], and 3) examined that young coconut water has an effect on lowering blood pressure in people with hypertension [12]. However, the three studies only mentioned young coconut water and coconut water. While in the market there are several types of coconut water, one of which is green coconut water which is known in the community as penjalin coconut water. According to researchers, green coconut water is coconut water that is better than other types of coconut water. When viewed from a price point of view, green coconut water is also more expensive. This is what attracts researchers to further investigate the benefits of green coconut water before performing aerobic physical activity on pulse recovery.

The purpose of this study was to determine how much influence green coconut water (Cocos nucifera) has on pulse recovery in the fifth, seventh and ninth minutes. While the expected contribution in this research is as an alternative to providing nutritional input to help accelerate pulse recovery in athletic athletes who can participate in two branch numbers in one match day so that it requires a contribution of scientific insight in meeting the nutritional needs of athletes, especially the fulfillment of fluids that can help. pulse recovery.

\section{Method}

Suggests the experimental research method can be explained as a method used to seek the treatment / effect of one thing for another when in controlled conditions [13]. The research method used pre-experimental design through a one-group pretest-posttest design. This research consists of two variables, independent and dependent. The independent variables include aqua mineral water (A1) and green coconut water (A2), while the dependent variable is pulse recovery (B). The population and sample in this study were all athletic athletes who are members of the PASI athletes in Pekalongan Regency, amounting to 13 athletes who have the criteria as athletes in the Pekalongan Regency athletics with the age of 15-22 years with a training ground at Widya Manggala Krida Kedungwuni Stadium. 
The exclusion criteria were research subjects who could not represent the sample, including the sample who was unwell and refused to be a respondent. The inclusion criteria in this study were having high blood pressure, having asthma, hypertension and being unwell due to staying up late. The exclusion and inclusion criteria were based on their effect on the same decrease in pulse rate and unusual occurrence. This study has limitations on the sample including a) the samples are male and female, b) giving drink to the sample for only 5 days, and c) No control feeding of samples.

\subsection{Pretest Implementation}

Day 1 (Monday, March 9, 2020) samples / athletes are collected into one group, then each athlete is given $300 \mathrm{ml}$ of mineral water with the aqua brand to drink 15 minutes before carrying out physical activity (aerobics) running $2.4 \mathrm{~km}$ together from start to finish. During this 15 minute break, the athletes are welcome to do a light warm-up, static and dynamic stretching. After the athlete reaches the finish line, the counting time begins with the athlete being allowed to walk lightly. In the fifth, seventh and ninth minute, each athlete has his / her pulse counted for 30 seconds via the wrist. The equipment used includes a whistle, stopwatch, pencil, notebook and measuring cup. The data obtained from these activities is used as the basis for dividing the control and experimental groups.

\subsection{Treatment}

According to Andika [12] Giving coconut water to the elderly for five days can lower blood pressure. That is the basis for the treatment for 5 days. The distribution of the control group (mineral water) consisting of 7 athletes and the experimental group (green coconut water) consisting of 6 athletes before the posttest implementation is Table 1.

Table 1. Treatment of giving drinks to each group

\begin{tabular}{|c|c|c|c|}
\hline Time & Exercise material & Vol & Fluid Volume \\
\hline Tuesday & Strength down & $70 \%$ & $1500 \mathrm{ml} / \mathrm{day}$ \\
Wednesday & Bounding & $5 \mathrm{Set}$ & $1500 \mathrm{ml} / \mathrm{day}$ \\
Thursday & Short Speed & $70 \%$ & $1500 \mathrm{ml} / \mathrm{day}$ \\
Friday & Abdominal plank & $10 \mathrm{set}$ & $1500 \mathrm{ml} / \mathrm{day}$ \\
Saturday & Agility & $70 \%$ & $1500 \mathrm{ml} / \mathrm{day}$ \\
\hline
\end{tabular}

\subsection{Post-test implementation}

The first picture will explain about the process of carrying out data collection in the control group, and in the second picture describes the process of carrying out data collection in the experimental group. Implementation of the post test was held on the 7th day (Sunday, 15 March 2020). Control group research design show in Figure 1 and research design of the experimental group show in Figure 2.

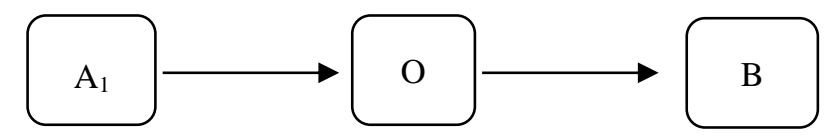

Fig. 1. Control group research design 


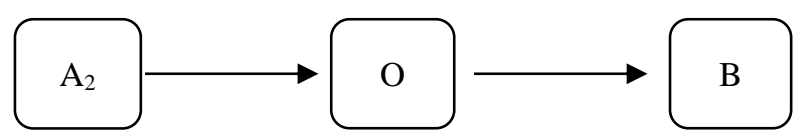

Fig. 2. Research design of the experimental group

Where: A1 as drink aqua mineral water; A2 as drink green coconut water; $\mathrm{O}$ as $2.4 \mathrm{~km}$ run test; and B as pulse recovery. The following variables are related: a) the drinks in question are Aqua mineral water and green coconut water (Cocos Nucifera) with a dose of $300 \mathrm{ml}$ each, given 15 minutes before doing the $2.4 \mathrm{~km}$ running test with start and finish together; b) pulse recovery in this study conducted a $2.4 \mathrm{~km}$ running test, measured pulse recovery at minutes five, seven and nine for 30 seconds on the wrist to find out how much the pulse decreased; and c) equipment used: A cloth, stopwatch, measuring cup, pencil and notebook.

\section{Results and Discussion}

This research was conducted for 7 days located at Widya Manggala Krida Krida Kedungwuni Stadium, the sample in this study consisted of 13 athletes in male and female athletics, where the first day was carried out a pre-test with the sample doing physical activity with a $2.4 \mathrm{~km}$ running test. After completion of the sample, the pulse recovery rate will be measured at minutes five, seven and nine for 30 seconds, from the data obtained then the sample is divided into control and experimental groups. On the second to the sixth day the control group was given $1500 \mathrm{ml}$ of aqua mineral water for each day and the experimental group was given 2 green coconut water drinks to drink every day. Then on the seventh day, a post-test was carried out with the control group given $300 \mathrm{ml}$ of aqua mineral water and the experimental group given $300 \mathrm{ml}$ of green coconut water. Drinks are drunk 15 minutes before doing physical activity to run $2.4 \mathrm{~km}$ together from start to finish. After completing the measurement of his recovery pulse on the wrist at the fifth, seventh and ninth minute in each group. Data processing using the SPSS program.

\subsection{Descriptive Test Results}

The Table 2 explains that the number of group samples is 7 athletes, with each athlete measuring the pulse recovery 3 times, namely at the fifth, seventh and ninth minutes, so that the number of control sample data is 21 .

Table 2. Descriptive analysis of the results of the decrease in pulse rate of the control group

\begin{tabular}{cccccc}
\hline Variable & N & Min & Max & Mean & Std Dev \\
\hline Pre & 21 & 42 & 62 & 51,38 & 5,723 \\
Post & 21 & 59 & 75 & 65,95 & 4,248 \\
Valid N & 21 & & & & \\
\hline
\end{tabular}

The Table 3 explains that the number of group samples is 6 athletes with each athlete measuring the pulse recovery 3 times, namely at the fifth, seventh and ninth minutes, so that the number of control sample data becomes 18 . 
Table 3. Descriptive analysis of the results of the decrease in pulse rate of the experimental group

\begin{tabular}{cccccc}
\hline Variable & N & Min & Max & Mean & Std. Dev \\
\hline Pre & 18 & 44 & 58 & 50,78 & 4,493 \\
Post & 18 & 60 & 78 & 71,00 & 5,190 \\
Valid N (listwise) & 18 & & & & \\
\hline
\end{tabular}

\subsection{Normality Test Results}

Table 4 showing Shapiro-Wilk normality test.

Table 4. Shapiro-Wilk Normality Test Results

\begin{tabular}{clcccccc}
\hline \multirow{2}{*}{ Group } & \multicolumn{3}{c}{ Kolmogorov-Smirnov ${ }^{\mathbf{a}}$} & \multicolumn{3}{c}{ Shapiro - Wilk } \\
\cline { 2 - 7 } & Statistics & df & Sig. & Statistics & df & Sig. \\
\hline \multirow{2}{*}{ Green coconut water } &, 126 & 18 &, $200^{*}$ &, 975 & 18 &, 881 \\
\cline { 2 - 7 } & Mineral water &, 164 & 21 &, 146 &, 959 & 21 &, 490 \\
\hline
\end{tabular}

Based on Table 4 indicates that the sig value indicates $>0.05$ that the data is normally distributed.

\subsection{Data Analysis Test Results on Mineral Water}

Table 5 showing result of t-test data analysis for aqua mineral water at 5,7 and 9 minutes.

Table 5. The results of t-test data analysis for aqua mineral water at 5, 7 and 9 minutes.

\begin{tabular}{|c|c|c|c|c|c|c|c|c|c|}
\hline \multirow{2}{*}{\multicolumn{2}{|c|}{ Minute }} & \multicolumn{5}{|c|}{ Paired Differences } & \multirow[b]{2}{*}{$\mathrm{t}$} & \multirow[b]{2}{*}{ df } & \multirow{2}{*}{$\begin{array}{l}\text { Sig.(2- } \\
\text { tailed) }\end{array}$} \\
\hline & & Mean & $\begin{array}{l}\text { Std. } \\
\text { Dev }\end{array}$ & $\begin{array}{c}\text { Std. Err } \\
\text { Mean }\end{array}$ & low & up & & & \\
\hline 5 & Pre - Pos & $-12,143$ & 8,315 & 3,143 & $-19,833$ & $-4,453$ & $-3,864$ & 6 & ,108 \\
\hline 7 & Pre - Pos & $-14,000$ & 5,508 & 2,082 & $-19,094$ & $-8,906$ & $-6,725$ & 6 & ,261 \\
\hline 9 & Pre - Pos & $-17,571$ & 7,413 & 2,802 & $-24,427$ & $-10,716$ & $-6,271$ & 6 & 081 \\
\hline
\end{tabular}

Based on Table 5, the sig value $>0.05$ then $\mathrm{Ha}$ (final hypothesis) is rejected, and Ho (initial hypothesis) is accepted, with the conclusion that there is no difference between the results of the pre-test post-test, which indicates that there is no effect of mineral water. Results t-test data analysis for grees coconut water at 5,7, and 9 minutes show in Table 6.

Table 6. Results of t-test data analysis for green coconut water (Cocos Nucifera) at 5, 7 and 9 minutes

\begin{tabular}{|c|c|c|c|c|c|c|c|c|c|}
\hline \multirow[b]{2}{*}{ Minute } & & \multicolumn{5}{|c|}{ Paired Differences } & \multirow[b]{2}{*}{ t } & \multirow[b]{2}{*}{ df } & \multirow[b]{2}{*}{$\begin{array}{l}\text { Sig.(2- } \\
\text { tailed) }\end{array}$} \\
\hline & & Mean & $\begin{array}{l}\text { Std. } \\
\text { Dev }\end{array}$ & $\begin{array}{l}\text { Std. Err } \\
\text { Mean }\end{array}$ & low & up & & & \\
\hline 5 & Pre - Pos & $-18,500$ & 7,635 & 3,117 & $-26,513$ & $-10,487$ & $-5,935$ & 5 &, 002 \\
\hline 7 & Pre - Pos & $-19,167$ & 4,401 & 1,797 & $-23,785$ & $-14,548$ & $-10,668$ & 5 &, 000 \\
\hline 9 & Pre - Pos & $-23,833$ & 7,834 & 3,198 & $-32,054$ & $-15,612$ & $-7,452$ & 5 & ,001 \\
\hline
\end{tabular}


Based on Table 6 , the sig value $<0.05$ then Ho (initial hypothesis) is rejected, and Ha (final hypothesis) is accepted, with the conclusion that there is a difference in the pre-test post-test, which means that there is an effect of green coconut water (Cocos Nucifera).

\subsection{The effect of green coconut water drink on the decrease in pulse rate in athletic athletes in Pekalongan Regency}

Based on the facts and existing theoretical studies, young coconut water has a content consisting of $17 \%$ potassium, $15 \%$ magnesium and $10 \%$ vitamin $\mathrm{C}$. The content of young coconut water can reduce pulse [8].

Young coconut water contains about $291 \mathrm{mg}$ of potassium per $100 \mathrm{ml}$ [7]. Young coconut water can normalize blood pressure. Potassium in coconut water balances the function of sodium in blood pressure imbalances [8]. Potassium lowers blood pressure is estimated by the mechanism of natriuresis in the kidney, endhotelium-dependent vasodilation, and the central effect through the renin angiotensin aldosterone (RAA) mechanism and an increase in the $\mathrm{Na}$ pump which decreases sympathetic nerve activity [7]. Potassium can lower systolic and diastolic blood pressure by inhibiting the release of renin so that it can help increase sodium and water excretion [9].

The mineral content in the form of potassium can keep blood vessel walls elastic, minimize blood vessel constriction, renin secretion, decrease Aldosterone and have the effect of activating $\mathrm{Na}-\mathrm{K}$ in the form of potassium derived from extra cellular fluids to cells, as well as sodium when activated. So that potassium can restore the pulse [14]. Researchers assume that the decrease in pulse recovery is due to the consumption of 2 green coconut water in 5 days 2 times a day (morning and evening). In addition, according to potassium is very useful in reducing diastolic and systolic blood pressure through inhibition of renin release which helps increase sodium and water excretion [15].

Researchers recommend green coconut water as an herbal drink that can be consumed regularly 2-3 glasses per day which serves as an alternative to non-pharmacological treatment to reduce the recovery rate.

\subsection{The effect of drinking mineral water and green coconut water on decreased pulse rate in athletic athletes in Pekalongan Regency.}

Based on the facts and existing theoretical studies, the results of the test calculations in the fifth, seventh and nine minutes respectively show the sig value $>0.05$ minutes $5=0.108,7$ minutes $=0.261$ and 9 minutes $=0.081$ so it can be concluded that it does not show the difference between pretest and posttest, so it means that there is no influence of mineral water. For the experimental group, the results of t-test calculations in the fifth, seventh and nine minutes respectively show the sig value $<0.05$ minutes $5=0.002,7$ minutes $=0.000$ and 9 minutes $=$ 0.001 so that it can be concluded that it shows the difference between pretest and posttest which means it is concluded that there is an effect that giving green coconut water can restore the pulse after physical activity.

These results can be seen from the decrease in the experimental group's pulse after doing physical activity running $2.4 \mathrm{~km}$ with the playing duration. The results of achieving the value of pulse recovery, researchers know that regular administration of green coconut water for 5 days can have an effect on reducing the pulse rate after physical activity. Provision of coconut water can restore the pulse faster than mineral water because green coconut water contains 
mineral electrolytes which contribute to replacing body fluids through sweat caused by physical activity.

The amount of sweat lost can be replaced by giving electrolytes. It is recommended to give anti-dehydration fluids containing components Aqua water contains $11-25 \mathrm{mg} / \mathrm{l}$ calcium, 6-22 $\mathrm{mg} / \mathrm{l} \mathrm{magnesium,} \mathrm{1-8} \mathrm{mg/l} \mathrm{potassium,} \mathrm{9-25} \mathrm{mg/l} \mathrm{sodium,} \mathrm{71-187} \mathrm{mg/l} \mathrm{bicarbonate,} \mathrm{chioride} \mathrm{1-}$ $25 \mathrm{mg} / \mathrm{l}$, sulfate $2-33 \mathrm{mg} / \mathrm{l}$, silica $62-87 \mathrm{mg} / \mathrm{l}$, TDS 88-190 mg/l, pH 6.7-7.2. However, these needs depend on gender, age, type of athletic branch, environmental origin, eating habits, exercise, smoking, history of parental disease and history of cardiovascular disease.

\section{Conclusion}

The results of this study concluded that there was an effect of giving green coconut water on pulse recovery in athletics in Pekalongan Regency. From the results of the conclusions of this study, the provision of green coconut water is better than mineral water and it is suggested for further researchers to do other sports with different treatments.

\section{Acknowledgement}

This research uses funding from lecturers' research funds through LPPM Muhammadiyah University Pekajangan Pekalongan. The researcher would like to thank those who have been involved in this research activity, including athletes and coaches of PASI Pekalongan Regency who were willing to be samples in this activity and students of the Physical Education study program who have helped the implementation process from preparing equipment, collecting data to making research reports.

\section{References}

[1] Hamidin, A.S. (2010). Kebaikan Air Kelapa. Yogyakarta: Media Pressindo.

[2] Laitano, O., Trangmar, S. J., De Melo Marins, D., Menezes, E. S., \& Da Silva Reis, G. (2014). Improved exercise capacity in the heat followed by coconut water consumption. Motriz. Revista de Educacao Fisica, 20(1), 107-111.

[3] Ivan Saefullah. (2013). "Perbandingan Waktu Pemulihan Pasca Olahraga Dengan Hiperhidrasi Menggunakan Minuman Air Putih dan Minuman Isotonik". Skripsi. UPI

[4] Kalman, D. S., Feldman, S., Krieger, D. R., \& Bloomer, R. J. (2012). Comparison of coconut water and a carbohydrate-electrolyte sport drink on measures of hydration and physical performance in exercise-trained men. Journal of the International Society of Sports Nutrition, 9(1), 1.

[5] Syafriani, R., Sukandar, E. Y., Apriantono, T., \& Sigit, J. I. (2014). The Effect of Coconut Water (Cocos Nucifera L.) and an Isotonic Drink on the Change of Heart Rate Frequency in the Rats Induced Hypertension. Procedia Chemistry, 13, 177-180.

[6] Chaubey, A., Sharma, M., \& Bhatnagar, B. (2017). Comparitive Study on Coconut Water, Carbohydrate Electrolyte Sports Drink and Sodium Enriched Coconut Drink on Measures of Hydration and Physical Performance in Athletes. IOSR Journal of Sports and Physical Education, 04(03), 46-51.

[7] Farapti dan Sayogo, S. 2014. Air Kelapa Muda - Pengaruhnya terhadap Tekanan Darah. (CDK-223). Vol. 1 No. 12, th 2001. 
[8] Darmawan, B.D. (2013). Diet Sehat Air Kelapa Untuk Kecantikan dan Penyembuhan macammacam Penyakit. Jogjakarta: Media Pressindo.

[9] Lingga, L. (2012). Terapi Kelapa Untuk Kecantikan dan Kesehatan. Jakarta: PT Elex Media Komputindo, Gramedia.

[10] Hatta, M. Susanto H., Zen M. (2016). Perbandingan pemberian air kelapa muda (cocos necufera I) dengan isotonik terhadap denyut nadi dan V02maks atlet remaja. (Jurnal Gizi Indonesia), 4 (2), 71 81. Universitas Diponegoro.

[11] Akhyar Padhli H. (2020). Pengaruh pemberian air kelapa terhadap denyut nadi pemulihan paska berolahraga (JORPRES), 16 (1), 1-6. Universitas Negeri Yogyakarta.

[12] Andika, F. Haniarti. Patintingan, A. (2018). Pengaruh pemberian air kelapa terhadap penurunan tekanan darah pada penderita hipertensi diwilayah kerja puskesmas Lanrisang Kabupaten Pinrang. (Manusia dan Kesehatan). 1 (3), 217-229. UMPAR

[13] Sugiyono (2015). Metode Penelitian Kombinasi (Mix Methods). Bandung; Alfabeta.

[14] Muttaqiin, A. (2009). Pengantar Asuhan Keperawatan Klien Dengan Gangguan Sistem Kardiovaskular. Jakarta: Salemba Medika.

[15] Almeida, M., Bottino, A., Ramos, P., \& Araujo, C. G. (2019). Measuring Heart Rate During Exercise: From Artery Palpation to Monitors and Apps. International Journal of Cardiovascular Sciences, 32(4), 396-407. 